\title{
Bioavailability of Chromium in Spiked Soil by Sequential Extraction and Its Absorption in Amaranthus hybridus
}

\author{
Siti Karimah ${ }^{1}$, Asep Saefumillah ${ }^{2}$, Askal Maimulyanti ${ }^{3}$ \\ \{siti.karimah@sci.ui.ac.id ${ }^{1}$, asep.saefumillah@sci.ui.ac.id ${ }^{2}$, askal_m@yahoo.com³ $\}$ \\ University of Indonesia $^{1,2}$, AKA Bogor Polytechnic ${ }^{3}$
}

\begin{abstract}
Accumulation of heavy metals in agricultural soils continues to be a worrying problem, such as chromium. Chromium may become contaminants in the soil and were suspected mobilized to food crops such as green spinach (Amaranthus hybridus). Bioavailability of the heavy metal speciation in spiked soil can be carried out by sequential extraction method by Tessier with different reagents to obtain five fractions, exchangeable, bound to carbonate, bound to $\mathrm{Fe} / \mathrm{Mn}$, bound to organic matter, residual and analysed by AAS. A. hybridus were harvested after 8 weeks, destructed by wet destruction and analysed with ICP-MS. Results showed the highest distribution in organic, Fe-Mn, and residual phases with percentage concentration $61.33 \% \pm 0.013,26.88 \% \pm 0.04,7.55 \% \pm 0.012$. Addition of chromium made biomass of plant decreased and its accumulation detected in root > stem > leaf with transfer and bioconcentration factor less than 1 meaning A.hybridus has potential as chromium accumulator.
\end{abstract}

Keywords: Heavy metals, plant, sequential extraction, soil

\section{Introduction}

Accumulation of heavy metals in agricultural soils continues to be a worrying issue [1][2][3]. The ability of mobility and persistence of heavy metals such as chromium can bring toxic effects to the soil and then food crops [4]. Its toxicity effects can impact microorganisms to genotoxic and mutagenic in humans [5][6]. The accumulation of metals in the environment has the potential to cause chain toxicity effects due to the mobility from aquatic sources to plants that affect the food chain of living things[4]. Therefore, the method of speciation of heavy metals in soil can be carried out with the Tessier method.

Speciation of chromium has effect to its mobility and toxicity. Chromium speciation can be analysed with sequential extraction by Tessier. This method has also been widely used to analyze the speciation and bioavailability of metals in soil and sediment [8]. This method can provide information about the speciation of heavy metals in soil, which can be formed as an exchangeable fraction, carbonate bound, iron and manganese oxide bound, organic bound, and residual. For example, studied metal about bioavailability of heavy metals like As, B, Cd, Co, $\mathrm{Cr}, \mathrm{Cu}, \mathrm{Fe}, \mathrm{Mn}, \mathrm{Ni}, \mathrm{Pb}$ and $\mathrm{Zn}$ in soil and food plants by comparing the extraction method used by BCR (The Community Bureau of Reference) [7] with the initial method proposed by Tessier, Campbell, \& Bisson [8] showed similar results, even the Tessier method can be more detailed 
because it is able to describe the associated fractions of manganese oxide and iron as separate amorphous and crystalline forms.

The leaves of Amaranthus are widely used, especially as food vegetables [9]. This plant has been shown to act as a metal accumulator in its leaves, such as the types A. hybridus and A. dubious tested with $\mathrm{Cd}, \mathrm{Ni}, \mathrm{Pb}$, and $\mathrm{Hg}$ metal contamination [10] and A.blitoides also has the ability to phytoremediate $\mathrm{Cu}, \mathrm{Zn}, \mathrm{Pb}, \mathrm{Cd}$, and $\mathrm{Cr}$ [11]. The accumulation of metals in Amaranthus hybridus has been shown to have an effect on plant physiological such as yellowish coloration on the stems and leaves and stunted growth [12]. Information of chromium fractions from sequential extraction and its accumulation in every part of plant (root, steam, and leaf) by sequential extraction can provide information about chromium availability that may be mobile to plant. Chromium accumulation in plant was measured to determine the distribution and level of accumulation. Therefore the aim of this study was give information about chromium speciation in soil sample and its accumulated potential in Amaranthus hybridus.

\section{Method}

\subsection{Materials}

Nitric acid 65\% (Merck), chloride acid 37\% (Merck), potassium dichromate (Merck), calcium chloride, sodium acetate anhydrate (Merck), acetic acid, peroxide acid, perchloric acid (Merck), hydroxylamine hydrochloride (Merck), Amaranthus hybridus seed (East West), atomic absorption spectroscopy (AAS) Shimadzu AA-3600, and inductively coupled plasma-mass spectroscopy (ICP-MS) Nex Ion 300 Perkin Elmer.

\subsection{Soil experiment}

Soil sample was collected from Grogol, Depok, West Java, topsoil $(0-30 \mathrm{~cm})$ with yellowish brown color. Soil sample was dried, passed through 2-mm sieve and ready to be spiked with $10 \mathrm{mg} / \mathrm{kg} \mathrm{K} \mathrm{Cr}_{2} \mathrm{O}_{7}$. Soil was spiked with $10 \mathrm{mg} / \mathrm{kg} \mathrm{Cr}$ from $\mathrm{K}_{2} \mathrm{Cr}_{2} \mathrm{O}_{7}$. Spiked soil was incubated for 15 days before planted. Experiment has been done with triplicate.

\subsection{Sequential extraction method with modification}

Soil sample was treated by sequential extraction to achieve five fractions, respectively, exchangeable, bound to carbonate, bound to Fe-Mn oxide, bound to organic matter, and residuals. Sequential extraction prepared 300 gram dry soil and then spiked with $\mathrm{Cr}$ from $\mathrm{K}_{2} \mathrm{Cr}_{2} \mathrm{O}_{7}$. The detail method is described in Table 1 .

Table 1. Detail of sequential extraction method

\begin{tabular}{|c|c|c|}
\hline Number of Fraction & Name of Fraction & Reagent \\
\hline 1 & Exchangeable & $0.5 \mathrm{M} \mathrm{CaCl}_{2}$ \\
\hline 2 & Bound to carbonate & $\begin{array}{c}1 \mathrm{M} \mathrm{NaOAc} \mathrm{pH} 5 \text { with acetic } \\
\text { acid }\end{array}$ \\
\hline 3 & $\begin{array}{l}\text { Bound to iron- } \\
\text { manganese oxide }\end{array}$ & $\begin{array}{c}0.04 \mathrm{NH}_{2} \mathrm{OH} . \mathrm{HCl} \text { in } 25 \% \\
(\mathrm{v} / \mathrm{v}) \mathrm{HOAc}\end{array}$ \\
\hline 4 & Bound to organic matter & $\begin{array}{c}0.02 \mathrm{M} \mathrm{HNO}_{3} \\
30 \% \mathrm{H}_{2} \mathrm{O}_{2} \mathrm{pH} 2 \text { with } \mathrm{HNO}_{3}, \\
3.2 \mathrm{M} \mathrm{NH}_{4} \mathrm{OAc} \text { in } 20 \%(\mathrm{v} / \mathrm{v}) \\
\mathrm{HNO}_{3} \text { dilute to } 20 \mathrm{ml}\end{array}$ \\
\hline 5 & Residual & Aqua regia \\
\hline
\end{tabular}




\subsection{Preparation of plant experiment and wet destruction}

Plant seeds collected from East West, green Amaranth (Amaranthus hybridus). Seed was sowed for 7 days and were transferred to spiked soil. Soil was moisturized every day to maintain $60 \%$ MWHC. Plant sample collected after 8 weeks. The plant rinsed with deionized water, dried in oven $80^{\circ} \mathrm{C}$, and dry weight measured. Then dry plant were finely ground and ready to be destructed.

Plant samples divided into root, leaf, and stem were put into each beaker and added 2.5 $\mathrm{mL} \mathrm{HNO}_{3} 65 \%$ then left overnight. The next day it was heated at $100 \mathrm{C}$ for 30 minutes, cooled and added $2.5 \mathrm{ml}$ nitric acid and $0.5 \mathrm{~mL} \mathrm{HClO}_{4}$. Then heated to $130{ }^{\circ} \mathrm{C}$ for 30 minutes, temperature was increased to $150^{\circ} \mathrm{C}$ (until the yellow fumes runs out). Then the temperature was gradually increased to $170^{\circ} \mathrm{C}$ and $200^{\circ} \mathrm{C}$ for 30 minutes until white fumes formed. Destruction was completed until white precipitate was formed about $1 \mathrm{~mL}$. The liquid precipitate was then filtered and dissolved to $10 \mathrm{~mL}$ and ready analyzed with ICP-MS.

The percentage of metal concentration of each fraction was calculated based on the total concentration detected. Then, as one of the factors in the mobility index of heavy metals from the soil to plants, the TF (transfer factor) and BCF (bioconcentration factor) test were calculated. According to [14], transfer factor can be calculated as the ratio of $\mathrm{Cr}$ concentration in aerial parts to $\mathrm{Cr}$ concentration in root.

$$
T F=\frac{C_{\text {Cr in aerial part }}}{C_{\text {cr in root }}}
$$

And also BCF can be calculated as ratio of metal concentration in tissue plant (stem, leaf) to that spiked soil [12]

$$
B C F=\frac{C_{C r \text { in tissue plant }}}{C_{C r \text { in soil }}}
$$

\section{Results and Discussion}

\subsection{Physiochemical properties of soil samples}

Soil samples were obtained from rice fields in Kampung Rawa Kalong, Grogol, Depok, West Java. The irrigation source is river water which is located around the field. Samplig position at 6'22'41 "S 106'47'30" E (latitude position 6 degrees 22 minutes 41 seconds and longitude position 106 degrees 47 minutes 30 seconds).

The bioavailability of heavy metals in soil can be influenced by several factors, namely soil $\mathrm{pH}$, soil texture, water resistance capacity (WHC), cation exchange capacity (CEC), and total organic carbon. The sample was in the acidic $\mathrm{pH}$ range with a $\mathrm{pH}$ of $\mathrm{H} 2 \mathrm{O} 4.4 \pm 0.00$ and a $\mathrm{KCl} \mathrm{pH}$ of $3.73 \pm 0.00$. An acidic $\mathrm{pH}$ value indicates that the soil sample has a fairly good $\mathrm{pH}$ condition as a medium for metal mobility even though there is a risk of lack of nutrients for plant growth intake [3]. The measurement results of the soil texture showed that the dominant sample was composed of $62 \%$ clay followed by $2 \%$ sand and $36 \%$ dust. The content of dust and sand is composed of primary minerals in the form of quartz ( $\mathrm{SiO} 2)$ and feldspar (MA13Si3O8) with $\mathrm{M}$ in the form of a combination of $\mathrm{Na}+\mathrm{K}+, \mathrm{Ca} 2+$.

The dominance of clay in the soil texture also affects the relatively common cation exchange capacity (CEC) of $20.98 \mathrm{cmolc} / \mathrm{kg}$. Soil texture of this sample dominated by clay, it can be a binding site where the metal cation exchange enters as a result of the formal charge -1 bond between $\mathrm{AlO} 3$ and $\mathrm{SiO} 4$. This can inhibit the movement of metals because they are bound to the surface of soil particles. Based on the results of soil characterization, the acidity of the 
soil $\mathrm{pH}$ which is in the acidic range and the cation exchange capacity impact the mobility of cation.

\subsection{Sequential Extraction of Soil}

The concept of sequential extraction based on extraction of metals which are more easily mobilized first and then continues to metals with lower mobility. The sequential extraction method based on the Tessier method can provide information on the metal bound phases, fractions 1 to 5, respectively, exchangeable fraction, bound to carbonate, Fe-Mn bound, organic bound, and residual. Extraction of metal starts with ionic reagents which able to carry metals that are on the ground surface of soils. Then the carbonate fraction is obtained with a buffer solution. The fraction bound to Fe-Mn is made in anoxic state, the organic fraction, the material needs to be oxidized, and last the residual fraction uses strong acids to break silica bonds [1] [2]. Based on Figures 1 and 2, distribution of $\mathrm{Cr}$ in the control soil was showed in the $\mathrm{Fe}-\mathrm{Mn}$ fraction, organic, and also residuals of $0.003 \pm 0.0001,0.0027 \pm 0.0002,0.00068 \pm 0.00 \mathrm{mg} /$ $\mathrm{kg}$ or $0.08 \% \pm 0.00,73.5 \% \pm 0.0002$, and $7.55 \% \pm 0.00$. The exchangeable and bound to carbonate fractions were below AAS detection limit.

After the addition of chromium spikes to the soil, the percentage of metal in the spiked soil fraction were increase. Percentage of exchangeable, bound to carbonate, bound to Fe-Mn, bound to organic matter, and residual fractions respectively $1.41 \% \pm 0.012,2.81 \% \pm 0.012,26.88 \% \pm$ $0.04,61.33 \% \pm 0.013,7.55 \% \pm 0.012$. The most $\mathrm{Cr}$ concentration was detected in fractions 3 , 4,5 with a concentration of $0.00453 \pm 0.0004,0.0097 \pm 0.00013,0.0014 \pm 0.00012 \mathrm{mg} / \mathrm{kg}$. Sequential extraction of Cr-contaminated soil with Camellia sinensis showed same results that chromium has low mobility, but it was mostly bound in the form of organic compounds, $\mathrm{Fe}$ Mn, and also residuals [3].

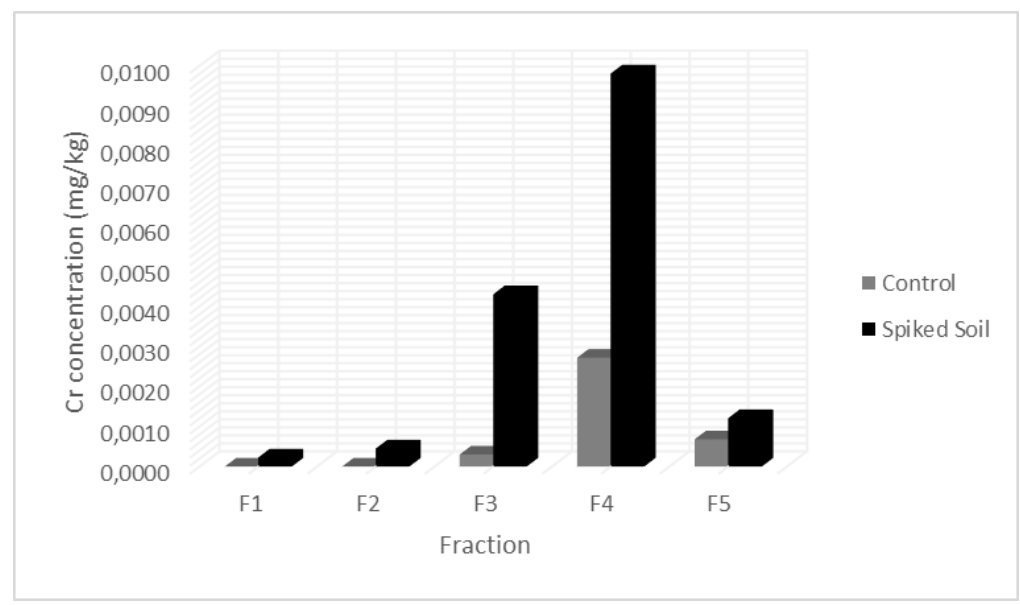

Fig.1 Cr concentration in control and spike soil $(\mathrm{mg} / \mathrm{kg})$ with $\mathrm{n}=3$. Fraction 1, 2, 3 for control soil were below detection limit. 


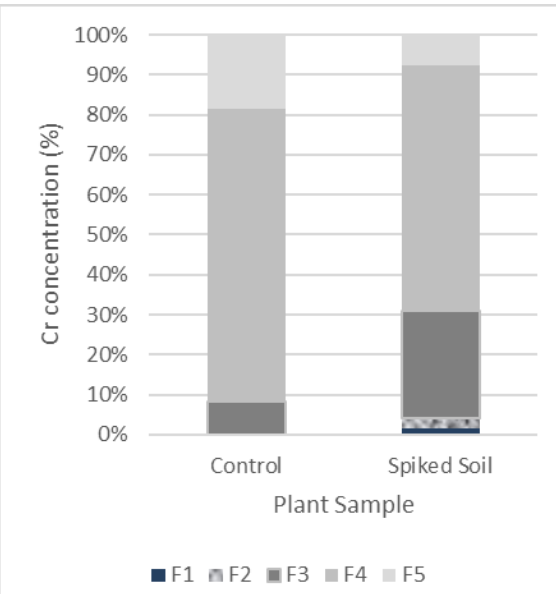

Fig 2. Percentage of $\mathrm{Cr}$ concentration in control and spike soil (\%) with $\mathrm{n}=3$

\subsection{Plant experiment}

Figure 3 showed accumulation $\mathrm{Cr}$ in every part of plant, root, stem, and leaf of A.hybridus. The highest concentration found in root, followed with stem, and leaf with $0,71,0,51$, and 0,14 $\mathrm{mg} / \mathrm{kg}$. Several studies have shown that Amaranthus hybridus is shown to be tolerant of heavy metal accumulation [6] even with low mobility due to its root uptake mechanism.

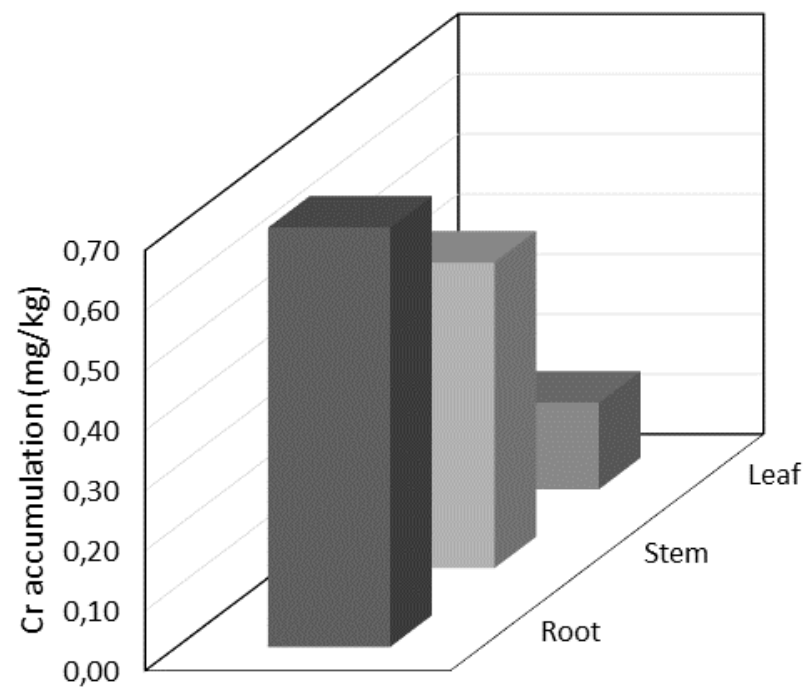

Fig 3. Cr concentration in Amaranthus hybridus $(\mathrm{mg} / \mathrm{kg})$

Contaminated soil also give effect that made yellowish leaves and stems tended to be thinner and slower leaf growth. The chromium-spiked plant biomass showed a decrease in biomass in every parts (Table 2). Table 2 showed that the accumulation of chromium in A.hybridus causes a decrease in the weight of the organ biomass in plants. This stunted growth 
due to metal toxicity which can inhibit the intake of nutrients needed for plant development [14]. Many studies show that the root is the plant organ that accumulates the most heavy metals. Its location in direct contact with the soil makes it easier for the roots to absorb heavy metals than aerial parts such as stems and leaves [4].

Table 2. Biomass of dry weight of A.hybridus

\begin{tabular}{llll}
\hline $\begin{array}{l}\text { Biomassdry } \\
\text { weight }(\mathrm{g})\end{array}$ & Root & Stem & Leaf \\
\hline Control & 0,063 & 0,031 & 0,086 \\
\hline Spiked Soil & 0,031 & 0,025 & 0,04 \\
\hline
\end{tabular}

Transfer factor values of root-stem and root-leaf also showed values less than 1 (Table 3). This value less than 1 that means A.hybridus has a potential as accumulator of chromium but not in hyperaccumulator type. Bioconcentration factor can show the effectiveness of metal accumulation in A.hybridus. Based on the results, the BCF value tends to be low from the range of 0.01 to 0.07 . This shows that the mobility of $\mathrm{Cr}$ from the root to the stem is greater than that of the leaf. Based on these two results, A.hybridus could potentially be a $\mathrm{Cr}$ accumulator.

Table 3. Transfer and bioconcentration factor of A.hybridus

\begin{tabular}{ccccc}
\hline \multicolumn{2}{c}{ TF } & \multicolumn{3}{c}{ BCF } \\
\hline Root-Stem & Root-Leaf & Root & Stem & Leaf \\
\hline 0,69 & 0,33 & 0,07 & 0,05 & 0,01 \\
\hline
\end{tabular}

Research on other plants such as Allium cepa has also shown an increase in $\mathrm{Cr}$ accumulation in plant parts such as leaves along with the addition of $\mathrm{Cr}$ spikes $(0-50 \mu \mathrm{g} / \mathrm{L})$ [15]. Cr accumulation also affects plant growth due to inhibition of its photosynthetic activity, for example in other Amaranthus species, Amaranthus viridis and Amaranthus cruentus [16]. $\mathrm{Cr}$ (III) has low solubility at $\mathrm{pH}<5.5$, however, at $\mathrm{pH}>5.5 \mathrm{Cr}$ (III) almost all of them precipitate and form stable bonds in the soil. Cr (III) and Cr (VI) are very unstable in soil and remains mobilized at acidic and alkaline $\mathrm{pH}$. $\mathrm{Cr}$ (VI) is usually in the form of oxyanions (HCrO4-, Cr2O72-, CrO42-). In plants, the mechanism of $\mathrm{Cr}$ (III) and $\mathrm{Cr}$ (VI) are not known for sure. This depends on the type of plant and the $\mathrm{Cr}$ speciation. $\mathrm{Cr}$ (III) species can enter the plant through passive transport without requiring the involvement of energy. $\mathrm{Cr}$ (VI) can be absorbed by plants through active transport (generally via the phosphate or sulfate pathways) because its structure resembles Cr (VI) with phosphate or sulfate [17].

\section{Conclusion}

This experiment showed that spiked soil distribute chromium mostly in the organic bound, $\mathrm{Fe}-\mathrm{Mn}$ bound, and residual. Amaranthus hybridus can absorb and accumulate $\mathrm{Cr}$ in the roots>stems> leaves. The value of transfer factor $\mathrm{Cr}$ in A.hybridus is in the range 0.33-0.69. This plant has potential to be chromium accumulator. 
Acknowledgement. This study was funded by Kementrian Riset dan Teknologi-Simlitabmas 2.0 period 2020 with contract number NKB-4853084/UN2.RST/HKP.05.00/2020.

\section{References}

[1] T. A. Adagunodo, L. A. Sunmonu, and M. E. Emetere, "Heavy metals' data in soils for agricultural activities," Data Br., vol. 18, pp. 1847-1855, 2018, doi: 10.1016/j.dib.2018.04.115.

[2] N. Barsova, O. Yakimenko, I. Tolpeshta, and G. Motuzova, "Current state and dynamics of heavy metal soil pollution in Russian Federation-A review," Environ. Pollut., vol. 249, pp. 200-207, 2019, doi: 10.1016/j.envpol.2019.03.020.

[3] O. Enya, C. Lin, and J. Qin, "Heavy metal contamination status in soil-plant system in the Upper Mersey Estuarine Floodplain, Northwest England," Mar. Pollut. Bull., vol. 146, no. June, pp. 292-304, 2019, doi: 10.1016/j.marpolbul.2019.06.026.

[4] Y. J. Cui et al., "Transfer of metals from soil to vegetables in an area near a smelter in Nanning, China," Environ. Int., vol. 30, no. 6, pp. 785-791, 2004, doi: 10.1016/j.envint.2004.01.003.

[5] A. Kushwaha, N. Hans, S. Kumar, and R. Rani, "A critical review on speciation, mobilization and toxicity of lead in soil-microbe-plant system and bioremediation strategies," Ecotoxicol. Environ. Saf., vol. 147, no. January 2017, pp. 1035-1045, 2018, doi: 10.1016/j.ecoenv.2017.09.049.

[6] T. L. DesMarias and M. Costa, "Mechanisms of chromium-induced toxicity," Curr. Opin. Toxicol., vol. 14, no. Iii, pp. 1-7, 2019, doi: 10.1016/j.cotox.2019.05.003.

[7] M. Alan and D. Kara, "Assessment of sequential extraction methods for the prediction of bioavailability of elements in plants grown on agricultural soils near to boron mines in Turkey," Talanta, vol. 200, no. March, pp. 41-50, 2019, doi: 10.1016/j.talanta.2019.03.031.

[8] A. Tessier, P. G. C. Campbell, and M. Bisson, "Sequential Extraction Procedure for the Speciation of Particulate Trace Metals," Anal. Chem., vol. 51, no. 7, pp. 844-851, 1979, doi: 10.1021/ac50043a017.

[9] E. G. Achigan-Dako, O. E. D. Sogbohossou, and P. Maundu, "Current knowledge on Amaranthus spp.: Research avenues for improved nutritional value and yield in leafy amaranths in sub-Saharan Africa," Euphytica, vol. 197, no. 3, pp. 303-317, 2014, doi: 10.1007/s10681-014-1081-9.

[10] T. Shi et al., "Inventories of heavy metal inputs and outputs to and from agricultural soils: A review," Ecotoxicol. Environ. Saf., vol. 164, no. August, pp. 118-124, 2018, doi: 10.1016/j.ecoenv.2018.08.016.

[11] G. C. Biswas, A. Sarkar, M. H. Rashid, M. Hassan Shohan, M. Islam, and Q. Wang, “Assessment of the irrigation feasibility of low-cost filtered municipal wastewater for red amaranth (Amaranthus tricolor L cv. Surma)," Int. Soil Water Conserv. Res., vol. 3, no. 3, pp. 239-252, 2015, doi: 10.1016/j.iswcr.2015.07.001.

[12] X. Zhang et al., "Tolerance and accumulation characteristics of cadmium in Amaranthus hybridus L.,"J. Hazard. Mater., vol. 180, no. 1-3, pp. 303-308, 2010, doi: 10.1016/j.jhazmat.2010.04.031.

[13] A. J. Zimmerman and D. C. Weindorf, "Heavy Metal and Trace Metal Analysis in Soil by Sequential Extraction: A Review of Procedures," Int. J. Anal. Chem., vol. 2010, pp. 1-7, 2010, doi: 10.1155/2010/387803.

[14] T. Karak et al., "Chromium in soil and tea (Camellia sinensis L.) infusion: Does soil amendment with municipal solid waste compost make sense?," Food Res. Int., vol. 64, pp. 114-124, 2014, doi: 10.1016/j.foodres.2014.06.006.

[15] S. Stasinos and I. Zabetakis, "The uptake of nickel and chromium from irrigation water by potatoes, carrots and onions," Ecotoxicol. Environ. Saf., vol. 91, pp. 122-128, 2013, doi: 10.1016/j.ecoenv.2013.01.023.

[16] G. Bashri, P. Parihar, R. Singh, S. Singh, V. P. Singh, and S. M. Prasad, "Physiological and biochemical characterization of two Amaranthus species under $\mathrm{Cr}(\mathrm{VI})$ stress differing in $\mathrm{Cr}(\mathrm{VI})$ tolerance," Plant Physiol. Biochem., vol. 108, pp. 12-23, 2016, doi: 
10.1016/j.plaphy.2016.06.030.

[17] M. Shahid et al., "Chromium speciation, bioavailability, uptake, toxicity and detoxification in soil-plant system: A review," Chemosphere, vol. 178, pp. 513-533, 2017, doi: 10.1016/j.chemosphere.2017.03.074. 